\title{
Kierkegaard e a prioridade do existente pessoal
}

\author{
Kierkegaard and the priority of the personal existent
}

\section{Paulo Barroso ${ }^{1}$}

1 Orcid: http://orcid.org/0000-0001-7638-5064

RESUMO: O tema deste artigo é o imperativo existencial de Kierkegaard, o existente pessoal que se impõe ao existente social. Este tema é transversal na obra deste autor e é pertinente, pois é sempre necessário e profícuo refletir sobre a condição humana e os estádios da existência atemporais que se tem de seguir. Qual é o cabimento dos três estádios da existência de Kierkegaard para a condição do indivíduo enquanto simples existente pessoal? A resposta a esta pergunta é o objetivo deste artigo. O objetivo é compreender a posição de Kierkegaard sobre a importância da assunção de uma existência pessoal, numa perspetiva atemporal. Este artigo é uma abordagem eminentemente teórica e concetual. A estratégia adotada incide na bibliografia de e sobre Kierkegaard e centra-se numa dimensão religiosa, o que justifica a sua preocupação com o indivíduo e, em particular, com o seu problema mais importante: a sua salvação. O resultado deste artigo é a demonstração da inevitabilidade da imitação de um modelo de existência, uma forma de reencontrar a unidade e a esperança de salvação, conduzindo à unidade interior e à verdadeira unidade antropológica, apenas possível com a fé. Conclui-se, com este artigo, que todos os seres humanos seguem um percurso escolhido e relativo de vida que os define e determina o que podem usufruir de uma existência inalienável e irrepetível.

Palavras-chave: existencialismo, essencialismo, Kierkegaard.

ABSTRACT: The theme of this article is Kierkegaard's existential imperative, a personal existent over a social existent. This theme is transversal in the work of Kierkegaard and is pertinent because it is always necessary and fruitful to reflect on the human condition and the timeless stages of existence that must be followed. What is the purpose of Kierkegaard's three stages of existence of the human condition as a mere personal existence? The objective of this article is to understand the Kierkegaard's position regarding the assumption of a personal existence, in a timeless perspective. This article is an eminently theoretical and conceptual approach. Following a strategy focused on the bibliography of and about Kierkegaard, the article emphasizes the religious dimension, which justifies Kierkegaard's concern for the individual and, namely, for his most important problem: his salvation. The result of this article is the demonstration of the inevitability to imitate a model of existence, a way to rediscover unity and the hope of salvation, leading to inner unity and true anthropological unity, which is only possible by faith. The article concludes that all human beings follow a selected and relative path of life, which defines them and determines what they can enjoy from an inalienable and unrepeatable existence.

Keywords: existentialism, essentialism, Kierkegaard.

\section{Introdução}

O tema deste artigo é o imperativo existencial de Kierkegaard. Segundo este imperativo, o existente pessoal impõe-se ao existente social. Considerando o existencialismo como quadro conceptual onde se enquadra Kierkegaard, este tema é transversal na obra deste autor. Este tema também é pertinente, na medida em que hoje, num mundo globalizado, tecnológico e hedonista em que vivemos, a tendência é inversa, ou 
seja, é para uma existência social, caracterizada pela partilha, como demonstram os usos predominantes das redes sociais. Todavia, o objetivo deste artigo não é relacionar o que não se afigura relacionável, isto é, confrontar o pensamento de Kierkegaard e o mundo globalizado e tecnológico atual.

É sempre necessário e profícuo refletir sobre a técnica, que marca a época atual e que sempre traz uma nova maneira de pensar sobre ela própria. "A technê pertence à criação, à poiesis; é algo poético", argumenta Heidegger (1977, p. 13). O indivíduo também pertence a uma criação, mas esta é divina. Por isso, também é objeto da poiesis de Deus. Mas a technê, mais propriamente, faz parte da "produção", a poiesis. Cada novo meio é uma técnica de comunicação poética ou "produtiva" que traz novos procedimentos e novas formas de estar no mundo; convida à reflexão. A obra de Kierkegaard, que é "geralmente considerado o primeiro existencialista” (Blackburn, 1997, p. 244), não deixa de ser interessante e pertinente para compreender o mundo atual e refletir sobre a condição humana e o hedonismo que a caracteriza, ou seja, é interessante confrontar um existente pessoal num tempo e numa época cada vez mais de existentes sociais.

Apesar de, na atualidade, ser profuso e hedónico o uso de redes sociais, através das quais as pessoas partilham subjetividades, privacidades e até intimidades que apenas a elas dizem respeito, o problema de investigação abordado neste artigo tem a ver com a necessidade de se refletir sobre os estádios da existência atemporais que se podem seguir. Qual é o cabimento dos três estádios da existência de Kierkegaard para a condição do indivíduo enquanto simples existente pessoal? A resposta a esta pergunta é o objetivo deste artigo. O objetivo é compreender a posição de Kierkegaard sobre a importância da assunção de uma existência pessoal, numa perspetiva atemporal, e refletir sobre a condição moderna do indivíduo à luz da posição existencialista de Kierkegaard. O objetivo deste artigo é, por conseguinte, analisar criticamente a questão de uma suposta supremacia da existência humana constituída, segundo Kierkegaard, numa dimensão estritamente pessoal.

Para esta abordagem eminentemente teórica e concetual, a estratégia argumentativa adotada toma necessariamente em conta a bibliografia de Kierkegaard, que é enquadrada numa dimensão religiosa. Esta bibliografia centra-se em torno de uma reflexão do autor sobre si mesmo e sobre a religião. Em Ponto de Vista Explicativo da Minha Obra como Escritor, o autor refere: "Eu fui e sou um autor religioso e toda a minha obra se refere ao cristianismo” (Kierkegaard, 1986, p. 22). A temática preferida de Kierkegaard é, essencialmente, a de teor religioso, o que justifica a sua preocupação central com o indivíduo e, em particular, com o problema mais importante do indivíduo: a sua salvação.

O resultado que se pretende alcançar e demonstrar é o que culmina na imitação de um modelo de existência. Este modelo é Cristo. Mais do que um ser ou entidade, Cristo é uma forma de reencontrar a unidade e a esperança de salvação, conduzindo à unidade interior do homem e à verdadeira unidade antropológica, que apenas com a fé se tomam possíveis. Conclui-se, com este artigo, que todos os seres humanos seguem um percurso relativo de vida que os define e determina o que podem usufruir de uma existência inalienável e irrepetível.

Mais do que um redutor e abrangente quadro concetual existencialista, Kierkegaard situa-se entre uma antropologia e um humanismo cristãos. Apesar da diferença radical entre o homem e Deus residir no pecado que determina a existência do primeiro, Kierkegaard concebe um deus-pessoa, uma entidade híbrida na qual participam o finito e o infinito. Com esta posição, Kierkegaard procura a desalienação do indivíduo. Neste ponto, o tema do imperativo existencial de Kierkegaard e a abordagem deste artigo são pertinentes e atemporais. No caso de Kierkegaard, a originalidade reside no estádio religioso ser o da desalienação, porque é neste estádio que o homem imerge da sua mais profunda interioridade e, por isso, se encontra perante Deus e reencontra a sua essência. 


\section{Posição de Kierkegaard sobre o existente pessoal}

O existente pessoal é, segundo a conceção de Kierkegaard, a existência de um ser humano que não está submetido no Universo, mas que se encontra isolado e fechado em si mesmo. Esta conceção difere de muitas outras, designadamente da conceção moderna de ser humano emanada do Humanismo Renascentista e aprimorada com o Iluminismo. Assim é, pois, como sustenta Norberto Bobbio (1951, p. 58), a conceção de ser humano do existencialismo retorna, com Kierkegaard, à antropologia pessimista da Reforma num tempo de triunfo do otimismo historicista. Neste sentido, a conceção de ser humano na obra de Kierkegaard define-se pela singularidade e opõe-se, por exemplo, ao sistema abstrato e racional de Hegel.

Em filosofia, conforme esclarece Michael Weston (2003, p. 5), a existência humana aspira ao seu objetivo final, a autodeterminação em termos de uma medida que encontra dentro de si, como o fim de sua capacidade de pensamento reflexivo. Kierkegaard usa o conceito de "existência" no e do mundo como uma esfera de atividade humana. Segundo Julia Watkin (2001, p. 81), este conceito de "existência” também pode referir-se ao esforço ético-religioso de uma pessoa e ao desenvolvimento pessoal na vida.

Considerando que o objetivo do indivíduo é tornar-se um ser espiritual, isso implica, para Watkin (2001, p. 59), a realização da individualidade única, pelo que Kierkegaard condena qualquer coisa que tende a apontar o indivíduo na direção oposta. Kierkegaard também condena o que denomina por "multidão" ou "público", i.e. grupos de pessoas formando pressão. Na distinção entre "multidão" e "comunidade", a multidão consiste simplesmente em pessoas em massa, números físicos, em que o grupo está formado pelo impensado e irresponsável, enquanto a comunidade consiste num grupo de indivíduos em que cada um é tentando a viver de acordo com uma idealidade ético-religiosa (Watkin, 2001, p. 59).

A posição de Kierkegaard sobre o existente pessoal é a de defesa de uma prioridade deste existente. Ao rebelar-se contra o sistema hegeliano que coloca o homem no lugar de Deus, Kierkegaard assume uma posição crítica desse sistema, pois Hegel ignora a perspetiva parcial, subjetiva e limitada a partir da qual se formam os juízos humanos (Blackburn, 1997, p. 244). É neste ponto que Kierkegaard acentua o primado da vontade e da escolha livre caraterizador do existente pessoal. O primado da vontade e a escolha livre não se restringe por causas nem razões. Segundo Kierkegaard, o que emana do homem, as suas ações e juízos, não possui nem pode possuir objetividade nem essencialismo unificador a todas as ações e juízos.

O pensamento de Kierkegaard carateriza-se, essencialmente, por uma perspetiva sobre a existência, constituindo uma reação ao sistema idealista e absoluto edificado por Hegel. Por isso, face a este sistema hegeliano, Kierkegaard opõe a "existência absoluta". O idealismo dialético absoluto (ou idealismo da razão absoluta) de Hegel terá fundamentado um quadro concetual kierkegaardiano inverso, à semelhança do que sucede com outros autores e respetivas perspetivas tipicamente pós-hegelianas, como Schopenhauer, Feuerbach ou Marx. Por isso, é dedutível a importância fundacional do sistema hegeliano a partir das teorias e perspetivas posteriores que surgiram como reação crítica.

O problema central sobre a prioridade do existente pessoal, segundo Kierkegaard, é enunciado pelas seguintes duas interrogações:

1) Qual é a conceção de indivíduo para Kierkegaard?

2) Em que medida a conceção de indivíduo de Kierkegaard se opõe a todas as conceções abstratas e sistemáticas, como a de Hegel?

Antecipando uma resposta para ambas as perguntas, procura-se explorar a prioridade dada por Kierkegaard ao existente pessoal em detrimento do existente social e, por consequência, ao existente inserido em qualquer sistema objetivo ou abstrato como o de Hegel. Prioridade que contribui para a afirmação de 
uma teoria kierkegaardiana da diferença do Ser. É este o aspeto importante a sublinhar e a explorar como ponto essencial e original da sua teoria.

O Ser, para Kierkegaard, apresenta-se de forma concreta e original. Existir é ser diferente, é fazer-se no tempo de forma original. Por ser interioridade, sentimento, paixão, experiência vivencial, o indivíduo é o oposto ao sistema que, como tal, dissolveria a singularidade, anularia o existente e, por conseguinte, a diferença entre os próprios indivíduos.

O racionalismo, que prevalece até Schopenhauer, exprime-se pelo princípio de que tudo quanto existe tem uma razão de existir. Esta razão de existir de tudo quanto existe sustenta-se no princípio da razão suficiente proposto por Leibniz, que depois é modificado e aprofundado por Schopenhauer na sua Quadrúpla Rair do Princípio da Razão Suficiente. Na Monadologia de Leibniz (1947, p. 14), este princípio de que "não existe nada que não tenha a sua razão de ser" aparece como o que é necessário para ter conhecimento de que não existem fatos ou verdades sem razões suficientes para o que eles devem ser.

Antes de Leibniz e de Schopenhauer, os traços basilares desta razão de existir ou de toda a racionalidade e inteligibilidade do Universo já tinham sido enunciados por Descartes, quando este admite nas $M e$ ditações Metafísicas a evidência como princípio da certeza e da verdade e, depois, estabelece, por puro raciocínio, a existência de Deus e da alma humana dotada de livre arbítrio. Descartes considera o pensamento racional (a res cogitans) como a essência do homem. O sujeito cartesiano repousa tranquilo na infinita perfeição do divino, razão pela qual confia no seu poder de conhecer e na possibilidade de acordo do seu pensamento com o real. Através da garantia de possuir ideias claras e distintas, o sujeito cartesiano possui a certeza e a verdade, mas desconhece, em contrapartida, a angústia do existente.

Kierkegaard opõe-se a todos os sistemas e conceções essencialistas e universalistas. Para Kierkegaard, o Cogito, Ergo Sum cartesiano não corresponde à realidade do existente pessoal. O racionalismo impregnado nesta máxima universal e objetiva de Descartes não pode condicionar a existência individual (Wahl, 1962 , p. 22). Kierkegaard considera que o existente pessoal não pode ser pensado, porque ficaria imobilizado, eternizado e sistematizado. Quanto muito, a fórmula de Descartes poderia ser invertida e ficar Sum, Ergo Cogito, dando Kierkegaard prioridade ao existente face ao pensamento.

Também Espinosa assume uma posição racionalista. Espinosa considera, por exemplo, a possibilidade ontológica, isto é, a necessidade absoluta da existência de Deus (Espinosa, 1992, p. 115; Moreau, 1982, p. 34). Se todo o sistema panteísta conduz à negação do livre-arbítrio e se tudo se confunde com a natureza divina, segundo Espinosa, não há lugar para a contingência humana e para os atos livres defendidos por Kierkegaard. Porquê? Porque ser contingente é próprio da essência de todo o ato livre, segundo Espinosa (1992, p. 149).

Além do racionalismo dogmático de Descartes e do racionalismo panteísta de Espinosa, Kierkegaard também se opõe ao racionalismo crítico de Kant e ao já mencionado racionalismo idealista de Hegel. Para o racionalismo crítico de Kant, a razão é a suprema legisladora; para o racionalismo idealista de Hegel, a razão é totalidade absoluta. Por isso, Kierkegaard se opõe a estas duas posições incompatíveis com a tese de um existente pessoal. Em relação a Hegel, Kierkegaard insurge-se designadamente contra as ideias de universalidade, momento histórico e totalidade.

Por fim, um paralelismo entre Kierkegaard e o essencialismo platónico. De acordo com Platão, os objetos que percebemos no mundo sensível constituem cópias de um mundo ideal, onde pré-existem os respetivos modelos perfeitos (Marías, 2004, pp. 55-56). Com esta perspetiva, Platão (2001, 514a; 2005, 81b) assinala dois mundos: o das essências e o das existências. A tese de Platão é a de que o segundo mundo imita o primeiro, participando nele. 
Basicamente há dois aspetos críticos nesta teoria platónica:

i) A distinção entre a essência e a existência;

ii) O primado da essência sobre a existência.

É sobre este segundo aspeto que se posiciona o existencialismo de Kierkegaard em negação do essencialismo platónico. Platão admite:

- Por um lado, um realismo da essência: a essência adquire uma realidade separada da existência, isto é, fora da existência, a essência é pura possibilidade que, na existência, se torna atualidade;

- Por outro lado, a essência como meio de tornar a existência inteligível: para o essencialismo platónico, a finalidade do existente é a atualização de uma essência.

Kierkegaard propõe um realismo da existência e afirma, por conseguinte, o primado da existência sobre a essência. Esta proposta contraria a subordinação platónica da existência à essência. Nesta perspetiva existencialista de luta contra a Ideia, Kierkegaard opõe-se, de certo modo, às conceções essencialistas e universalistas da História da Filosofia, como a de Platão, mas também como as de Descartes, Espinosa ou Hegel. Desde Platão até Hegel está balizada, segundo Kierkegaard, a tradição filosófica que urge refutar.

Kierkegaard opõe-se não só ao essencialismo platónico como também a Platão enquanto pensador sistemático. Esta dupla oposição deve-se à resistência de Kierkegaard contra todas as formas de essencialismo e de pensamento sistemático. A fórmula platónica das ideias, segundo a qual o pensamento é o antípoda do real, subjaz às correntes idealistas e pressupõe uma espécie de verdade metafísica anterior à existência concreta. Kierkegaard não podia aceitar a existência enquanto devir, a existência inteligível em função de uma verdade intemporal, porque considera que o único real é a existência. É neste sentido que Kierkegaard nega a prioridade da essência sobre a existência e defende, precisamente, o contrário, isto é, a prioridade do existente sobre qualquer forma de essencialismo.

\section{Compreensão geral da posição de Kierkegaard}

Kierkegaard recusa considerar o indivíduo como um momento no desenvolvimento da realidade (Wahl, 1962, p. 23). Ao assumir esta posição, Kierkegaard confronta Hegel, para quem tudo o que existe apenas existe em relação a uma totalidade. A ideia hegeliana de universal compreende tudo e todos, porque é realidade absoluta e eterna.

De acordo com o idealismo de Hegel, a Ideia revela-se na História; a realidade absoluta ou o fundo do Ser é a Ideia, o Espírito. Esta perspetiva aproxima-se do pensamento de Platão. Contudo, Platão considera que os fenómenos dados na experiência sensível são apenas aparências ilusórias, isto é, imagens móveis das ideias eternas. Se para Platão a ideia é eterna e o que está em devir é ilusório, para Hegel, pelo contrário, a Ideia ou o Espírito Absoluto é a essência do Ser que se revela na História. Assim, a diferença essencial entre os idealismos de Platão e Hegel reside na não negação do devir por parte de Hegel.

Efetivamente, Hegel considera o devir como a própria História do Espírito Absoluto, isto é, a odisseia do Espírito que se realiza por etapas sucessivas até chegar à plena consciência de si mesmo. A Ideia realiza-se por etapas através da História dos homens. Na Fenomenologia do Espírito, Hegel sustenta a história do espírito humano, a história do modo como a consciência evolui das formas rudimentares do conhecimento sensível até ao saber absoluto. Esta evolução progressiva da consciência (consciência enquanto o que o Ser é para si) é o produto de toda a evolução histórica. A Fenomenologia do Espirito é o itinerário da transformação da consciência, o caminho que a consciência segue é a história detalhada da formação da própria consciência.

Para Hegel, tudo o que acontece está dirigido para um fim último do mundo (Hartmann, 1983, pp. 
633-647). Na visão de Hegel, a arte, a religião e a filosofia estão referidas ao Absoluto. Neste sentido, em Filosofia do Direito, Hegel (2001, p. 18) admite que "todo o racional é real e todo o real é racional" no seu caminho para o Espírito Absoluto. Esse caminho sugere que se divinize o momento último, isto é, a época atual como a que possui o sentido e o fim da evolução anterior. Para Hegel, o realmente real é racional; o Ser é uma abstração metafísica e sistemática. Só há uma realidade verdadeira e plena: a totalidade racional. Há um panlogismo pelo qual tudo é razão, tudo é o divino, tudo quanto existe só existe pela sua relação com o todo. Há uma identidade entre real e racional. Isto significa a negação de todos os dualismos. A síntese do projeto filosófico hegeliano apresenta-se pelo pensar, que é também ser. A razão manifesta-se no real, que é suscetível de ser pensado na razão. Há uma total identidade entre a racionalidade e a realidade. Se não fosse racional, o real não seria apreendido e concetualizado.

À objetividade e à totalidade hegeliana, Kierkegaard opõe a verdade como subjetividade. Para Kierkegaard, o caminho para um saber absoluto e objetivo traçado por um sistema faz esquecer o existente pessoal. Segundo Kierkegaard, Hegel comete o erro de querer explicar todas as coisas. Por isso, o existencialismo kierkegaardiano defende que as coisas não devem ser explicadas, mas vividas (Wahl, 1962, p. 25). Vividas como fez Sócrates, o existente paradigmático para Kierkegaard, o primeiro dos existentes. Se ainda hoje sabemos pouco acerca de Sócrates é porque este viveu, subsistiu fora da esfera do conceito, pois a existência não é definível (Howland, 2006, p. 207). Em Sócrates existe algo que escapa à ciência histórica (Wahl, 1962, p. 26, 42; Platão, 2009, pp. 30-31).

No pensamento de Kierkegaard, a razão perde a sua importância. Ao contrário do que defende Hegel, Kierkegaard faz uma crítica do sistema hegeliano ao afirmar que:

- O sistema suprime a existência;

- O pensamento abstrato ignora o concreto;

- A interioridade existencial, a subjetividade, é o que interessa mais ao indivíduo e é descurado no sistema especulativo hegeliano.

Ao defender a tese da singularidade do indivíduo, Kierkegaard investe contra todas as formas de sistema. Kierkegaard considera que o sistema não pode dar conta da realidade, simplesmente porque:

a) O sistema é universal e a realidade é singular;

b) O sistema é abstrato e a realidade é concreta;

c) O sistema é racional e a realidade é irracional e é paixão;

d) O sistema é concebido como eterno e a realidade é efémera.

Resumindo, o sistema é tudo menos a realidade. O sistema é o que não é a realidade; a realidade é tudo menos o sistema. Para Kierkegaard, o sistema, cujo representante exponencial é Hegel, nada nos pode informar sobre o que existe de mais íntimo, significativo e sofrido no existente pessoal: as suas angústias, desesperos, aspirações, paixões, etc.

Por conseguinte, entre Kierkegaard e Hegel existe uma radical diferença entre uma perspetiva existencial e uma perspetiva sistemática. Tendo em conta o que foi abordado relativamente às perspetivas de Platão e de Hegel, é interessante constatar a radical oposição entre uma forma de pensamento essencialista e uma outra forma de pensamento existencialista.

Efetivamente, com uma perspetiva existencialista, Kierkegaard inaugura uma nova conceção sobre o ser humano que pode ser representada pelo conceito de "pensador existencial ou subjetivo". Esta nova formulação teórica sobre o ser humano emana do confronto proposto por Kierkegaard face ao idealismo sistemático de Hegel. Assim, ao conceito de "pensador sistemático e abstrato" representado na perspetiva hegeliana, Kierkegaard contrapõe o conceito de "pensador existencial". Basicamente, trata-se de uma contraposição a toda a perspetiva sistemática e objetiva. Esta contraposição constitui um traço caraterístico do 
pensamento existencialista em geral.

Todavia, ao se confrontar o pensador existencial ao pensador sistemático, coloca-se em causa um problema elementar: Como se comporta o pensamento de uma pessoa face à sua existência? Atendendo ao que foi exposto, é com naturalidade que se assumem duas posições antagónicas face a esta pergunta: a de Hegel e a de Kierkegaard.

O pensamento sistemático de Hegel carateriza-se assim:

i) Hegel parte do princípio de que o ser humano é um pensador abstrato que, no seu ato de pensar, se movimenta numa zona de pensamento puro, abstrato, sem atender às particularidades e pressupostos da sua existência;

ii) Circunscreve-se ao pensamento puro (a realidade é apenas o pensamento) e escapa à realidade concreta ou à experiência vivencial;

iii) Pensa-se a partir de uma atitude puramente idealista ou teorética e permanece-se desinteressado no seu conhecer;

iv) Por ser um pensamento abstrato, absoluto, objetivo, é também indiferente ao sujeito pensante e à sua existência;

v) Apreende-se o real de uma forma conceptual e sistemática.

Por seu turno, o pensamento existencial de Kierkegaard carateriza-se assim:

i) Kierkegaard parte do princípio de que o ser humano é um pensador existencial, cujo pensamento, ao contrário do que propõe Hegel, está determinado pelas particularidades da vida concreta e, por isso, deixa de ser um fim em si mesmo e passa a servir a sua correspondente existência;

ii) Circunscreve-se aos pressupostos, particularidades e interioridades da existência, que é estranha ao pensamento;

iii) O pensador subjetivo nunca é desinteressado, porque o seu pensamento está enraizado no seu existir, na vida humana;

iv) O pensador subjetivo encontra-se interessado no seu pensamento ao ponto de existir nele;

v) Exclui-se a possibilidade de apreensão conceptual e de sistematização racional.

Face às caraterísticas de cada uma destas duas posições antagónicas, deduz-se uma transversal diferença entre um existente social de Hegel e um existente pessoal de Kierkegaard. Dada a importância concedida por Kierkegaard ao indivíduo, isto é, ao existente pessoal, e tendo em conta, conforme se referiu, a sua conceção de indivíduo baseada na singularidade existencial, ao existente pessoal se contrapõe, com naturalidade, o existente social. É também inevitável que Kierkegaard critique e refute a ideia de "multidão" entendida como mentira, objetividade, ausência de liberdade, irresponsabilidade e indiferença.

Existe uma relação inversamente proporcional entre o existente pessoal e o existente social. O existente pessoal é o Ser singular, subjetivo, diferente dos demais. O existente social é o Ser plural, objetivo, indiferente. Para Kierkegaard (1986, p. 98) todo o indivíduo inserido na espécie é mais do que a espécie. Em Ponto de Vista Explicativo da Minha Obra como Escritor, Kierkegaard (1986, p. 102) afirma: "A multidão compõese, de fato, de Indivíduos; deve estar, portanto, ao alcance de cada um tornar-se no que é, um Indivíduo; absolutamente ninguém está excluído de o ser, exceto quem se exclui a si próprio, tornando-se multidão". Segundo Kierkegaard:

O indivíduo compreendido, não no sentido da distinção ou do talento especial, mas no sentido em que todo o homem, sem exceção, o pode e deve ser, deve pôr a sua honra em ser um Indivíduo, e nisso encontrará verdadeiramente a sua felicidade. (Kierkegaard, 1986, p. 108).

Conforme se deduz a partir destas duas citações, compreende-se que Kierkegaard se insere numa corrente de pensamento que se posiciona contra o conceito idealista, dialético e histórico de progresso, bem 
como a consequente participação ativa do indivíduo na vida coletiva. Kierkegaard propõe um ideal de vida em que o individuo se encontra independente do Estado e da comunidade.

O pessimismo está inerente ao individualismo, à apologia da personalidade privada, ao culto da originalidade pessoal, à exaltação das virtudes individuais ou a todas as designações subjetivistas que expressam a prioridade do existente pessoal na perspetiva de Kierkegaard e que convertem o indivíduo num fim absoluto em si mesmo. Assim, à dimensão existencialista de Kierkegaard se associa uma atmosfera necessariamente pessimista, através da qual o existente pessoal se encontra dilacerado pelo desespero no interior de si mesmo.

Por um lado, Kierkegaard propõe o retorno do indivíduo a si mesmo, para que este compreenda a sua própria dimensão de miséria, de limitação e de necessidade; por outro lado, defende a desvinculação da dimensão individual da sua base social. O objetivo desta perspetiva é a constituição do indivíduo e não a do bem-estar comum.

De acordo com Kierkegaard, ser indivíduo em si mesmo é diferente de ser indivíduo comunitário, estar inserido no sistema. Como a corrente prefere o indivíduo à humanidade, ou seja, o indivíduo único à multidão, Kierkegaard prefere, consequentemente, o existente pessoal ao existente social. Kierkegaard defende, deste modo, que a existência não pode ser reduzida a um momento da evolução da Ideia, como propõe o sistema hegeliano. Numa espécie de auto-retrato, Kierkegaard traça assim as caraterísticas elementares do existente pessoal:

Melancólico, incuravelmente melancólico como era, levava no fundo cruéis feridas depois de ter cortado, no desespero, com o mundo e as coisas do mundo; submetido, desde a infância, a uma severa educação onde se me observava que a verdade está votada ao sofrimento, à troça, ao insulto, e dedicando todos os dias um certo tempo à oração e à meditação, era, a meus olhos, um penitente. (Kierkegaard, 1986, p. 56).

Na conceção de Kierkegaard, o ser humano é caraterizado pela singularidade. A verdade não reside no existente social, na multidão, mas no existente pessoal, no individual (Kierkegaard, 1986, p. 99). Ao considerar que a verdadeira realidade é o existente, o singular, Kierkegaard contraria a perspetiva totalizadora de Hegel, segundo a qual o universal é a verdadeira realidade. Em Ponto de Vista Explicativo da Minha Obra como Escritor, Kierkegaard sustenta:

A minha obra brotou de uma irresistível necessidade interior, que ela foi a única possibilidade oferecida a um melancólico profundamente humilhado, o honesto esforço de um penitente com vista a reparar, se possível, fazendo um pouco de bem à custa de todos os sacrifícios na disciplina ao serviço da verdade. $[. .$.$] Não pretenderia [. .$.$] impor a alguém o que unicamente diz respeito à minha pessoa privada e que,$ a meus olhos, é, contudo, de grande importância para explicar a minha personalidade de autor. (Kierkegaard, 1986, p. 23).

A transcrição acima remete para uma posição subjetivista. É Kierkegaard quem melhor se autorepresenta, porque se enquadra nelas como existente concreto, sujeito individual que existe num bic et nunc vivencial e, por conseguinte, rejeita qualquer visão abstrata sobre o ser humano. De acordo com Kierkegaard, o humano realiza-se no indivíduo e não na abstração de um conceito universal de humanidade. A atenção do indivíduo é dirigida fundamentalmente para si próprio. O ponto de partida é a análise existencial do indivíduo enquanto existente. Apenas existe o singular, na medida em que só interessa a Kierkegaard o ser humano como o único e verdadeiro singular; aquele que vale mais do que a espécie; aquele que tem 
consciência da sua singularidade. O universal não passa de uma abstração. Por isso, a tarefa do pensador existencial é valorizar a existência singular contra o abstrato e o geral, isto é, contra a conceção de indivíduo como abstração sem consciência, sem realidade substancial.

Para Hegel, o geral é mais substancial, mais real, mais concreto do que o particular. Os indivíduos são momentos ou acidentes e existem na medida em que fazem parte de uma ideia objetiva, de uma totalidade orgânica. Mas o indivíduo não é abolido no sistema hegeliano; é afirmado orgânica e dialeticamente como espírito subjetivo, objetivo e absoluto.

Nesta perspetiva, o homem real é o indivíduo e não o homem como género. Mas isto não significa que todos os homens sejam imediatamente singulares, porque o homem vive no seio da multidão como um cidadão, ou seja, como elemento de uma estrutura, podendo e devendo tornar-se um singular se compreender o sentido da sua própria existência (Weston, 2003, p. 34). Este sentido é existir fora de todas as ordens estabelecidas, isto é, o que significa ser um singular.

\section{Do desespero aos três estádios de existência}

A conceção sobre o ser humano define, neste caso, uma perspetiva existencialista. Esta perspetiva inclui estados de espírito angustiantes, como o desespero, isto é, estados penosos para suportar uma dada existência. O desespero é não só um conceito importante na obra de Kierkegaard como também é um elemento vivencial e presente na condição humana. De tal modo assim é que o estado de desespero acompanha a existência humana. O desespero assume uma dimensão universal, segundo Kierkegaard:

Assim como talvez não haja, dizem os médicos, ninguém completamente são, também se poderia dizer, conhecendo bem o homem, que nem um só existe que esteja isento de desespero, que não tenha lá no fundo uma inquietação, uma perturbação, uma desarmonia, um receio de não se saber o quê de desconhecido ou que ele nem ousa conhecer, receio duma eventualidade exterior ou receio de si próprio; tal como os médicos dizem duma doença, o homem traz em estado latente uma enfermidade, da qual, num relâmpago, raramente um medo inexplicável lhe revela a presença interna. E de qualquer maneira jamais alguém viveu e vive, fora da cristandade, sem desespero, nem ninguém na cristandade se não for um verdadeiro cristão; pois que, a menos de o ser integralmente, nele subsiste sempre um grão de desespero. (Kierkegaard, 1947, p. 47).

O desespero é universal e inevitável. É também esta a interpretação rigorosa de Regis Jolivet acerca da posição de Kierkegaard relativamente ao desespero:

É impossível escapar ao desespero. A ausência de desespero equivaleria rigorosamente ao nada. [...] Para escolher o eterno, temos de desesperar daquilo que somos e do que temos na ordem do finito. O homem [...] esbarra sempre com os seus próprios limites; verifica e sente que o mundo inteiro não o pode completar e que também não pode completar-se a si mesmo. A sua existência ou consiste na sua relação com o transcendente [...] ou então não é nada [...]. O desespero desenraíza o homem de si mesmo como ser finito, entrega-o a si mesmo naquilo que tem de eterno. (Jolivet, 1975, p. 57).

O homem pode também fechar-se dentro de si mesmo e o desespero toma-se, assim, um "contra Deus", um desespero demoníaco que ora é desafio ora se apresenta como ausência de desespero (Jolivet, 1975, p. 58). Existe a possibilidade de um desespero saudável e salvador. "É a porta que se abre para a transcendência do absoluto", provocando o desprendimento e a superação dos limites do homem, que se enche de verdade e existe verdadeira e plenamente (Jolivet, 1975, p. 58). 
Retornando às duas perguntas colocadas na problematização, torna-se inevitável abordar um dos aspetos mais importantes da obra de Kierkegaard: os três estádios de existência. Conforme se deduz na citação anterior de Kierkegaard, o existente pessoal concretiza-se no existente religioso. Este é revelador da essência humana. Nos estádios da existência, o indivíduo existe como possibilidade, tendo a opção de dar o salto entre esses estádios.

Deve responder-se claramente à pergunta 1), sublinhando-se a supremacia do estádio religioso da existência para a conceção do indivíduo e como resultado de um percurso. Do mesmo modo, na pergunta 2) realça-se a peculiaridade da conceção do indivíduo de Kierkegaard. Por isso, esta conceção é oposta radicalmente a todas as conceções abstratas e sistemáticas, como a de Hegel.

Os três estádios de existência são momentos da história do indivíduo. Momentos que conduzem ao encontro do indivíduo com Deus. O homem situa-se perante Deus numa relação interpessoal que consiste em amor, devoção, sofrimento, temor, tremor, auto-consciência de pecador (herança do pecado original). O existente pessoal torna-se um Ser à medida de Deus (Weston, 2003, p. 115). É no estádio religioso que Kierkegaard concebe a suprema realização do existente pessoal. A verdadeira essência humana apenas é almejada pelo existente religioso. Para Kierkegaard, segundo Frederick Copleston (1996, p. 273) "O indivíduo existente por excelência é o indivíduo perante Deus, o homem no ponto de vista da fé".

Nesta perspetiva, é razoável supor que Kierkegaard assume uma posição em defesa do homem, mas também em defesa de Deus. Kierkegaard situa-se entre uma antropologia e um humanismo cristãos. Apesar da diferença radical entre o homem e Deus residir no pecado inerente ao primeiro, Kierkegaard concebe um deus-pessoa, uma entidade híbrida na qual participam o finito e o infinito. Com esta posição, Kierkegaard procura a desalienação do indivíduo. A desalienação é um conceito e um processo importante para a condição humana. Apesar de a desalienação já ter sido enunciada por Feuerbach e Marx, a originalidade reside, com Kierkegaard, no estádio religioso ser o da desalienação, porque é neste estádio que o homem imerge na sua mais profunda interioridade e, por isso, se encontra perante Deus e reencontra a sua essência.

O caminho existencial do indivíduo realiza-se dialeticamente, por conseguinte, através de três estádios, segundo Kierkegaard: o estético, o ético e o religioso. Este caminho significa um percurso pessoal e interior rumo à perfeição. Todavia, é um caminho impregnado de sofrimento (Weston, 2003, p. 46). A consciência do pecado está ligada intimamente à angústia e ao sofrimento. O sofrimento é o fator decisivo da existência religiosa; é a expressão da relação com a felicidade eterna; é o sentido para a salvação.

Sobre a importância do sofrimento, Nietzsche (2002, pp. 51-52) desenvolve, em A Origem da Tragédia, a tese paradoxal relativa ao povo que valorizava tanto a razão, a ordem e o controlo das paixões e que teve a necessidade de criar uma arte, a tragédia, onde se expressa o irracional e o misterioso. A tragédia grega serve para compreender como o sofrimento tornou o povo grego tão belo. A dimensão estética adquire uma perspetiva ontológica. Há um trânsito do estético para o metafísico. É sobre as categorias do belo que Nietzsche apresenta as suas considerações metafísicas. Para Nietzsche, o povo grego teve a necessidade de sentir sofrimento e afligir-se com a tragédia e, só assim, pôde edificar a arte e o esplendor estético. O pessimismo não é signo de declínio; pelo contrário, é signo de elevação pela arte. Nietzsche reconhece uma relação profícua entre os gregos e a dor, da qual se desenvolve a sua sensibilidade e nasce a obra de arte. O povo grego era caracterizado por uma sensibilidade simultânea ao sofrimento e à arte. A origem da arte está na tragédia, no sofrimento humano.

Esta interpretação de Nietzsche tem paralelo com os estádios de existência de Kierkegaard. Segundo Jean Wahl: 
Kierkegaard usou de rodeios, descreveu primeiro a experiência estética, mostrou o que há de pouco satisfatório na experiência estética, e como é preciso substituí-la pela experiência ética. (...) Mas acima da experiência ética, como acima da experiência estética, há a experiência propriamente religiosa. (Wahl, 1962, p. 106).

O primeiro estádio é o estético, o do imediatismo. Apenas proporciona prazer o que é imediato ou novidade. O esteta só conhece o instante e não obedece a padrões morais universais. O esteta vive na exterioridade e carateriza-se pela superficialidade; é um homem solteiro, vive consoante os sentidos, emoções, impulsos (Weston, 2003, p. 46). A realidade é a do ponto de vista da sensibilidade: o esteta procura incessantemente novos prazeres. O prazer está ligado aos sentidos (estádio hedonista): o homem é comandado pelo desejo, nomeadamente pelo desejo erótico (como Don Juan, figura que representa a infidelidade, a sedução múltipla, o usufruto). A existência humana é determinada pela fantasia e a imaginação, mas não tem unidade, visto que é apenas sequência de momentos justapostos, existência amoral, dispersa, sem forma e instável. A sedução não dá continuidade à existência do esteta que, por isso, evita as ligações estáveis. A repetição é impossível, o esteta não conhece duas vezes o mesmo estado de alma e termina no desespero e na perdição, porque vive sempre insatisfeito. $\mathrm{O}$ instante não é vivido em plenitude, porque é acompanhado de angústia. $O$ esteta vive o instante na angústia de o perder. A angústia é um estado de incerteza perante o futuro e constitui a essência da existência. Não há nem pode haver fruição plena do prazer imediato. Por isso, o esteta vive na recordação e a sua existência toma-se paradoxal. A dinâmica do desejo transforma cada desejo satisfeito em melancolia e aspiração a novas experiências. A ironia apresenta formas sucessivas e gradativas: da exterioridade e superficialidade para a sua consciencialização. É esta dimensão crítica da ironia que permite tomá-la como zona-limite entre o estádio estético e o estádio ético.

Tal como a ironia socrática permite a consciencialização do vazio espiritual e possibilita o salto qualitativo para a maiêutica, também a ironia kierkegaardiana permite o salto qualitativo para a interioridade do estádio ético. O finito revela-se à consciência como irrisório. Não há cura possível para a situação do esteta. A permanência na sensibilidade significaria cair na "doença mortal", no desespero. Passar a outro estádio, dar o salto, implica a escolha, que é recusa, sofrimento e angústia. A ironia é o reconhecimento da superficialidade, da futilidade, do caráter fugaz do estádio estético; permite o distanciamento face ao mundo do prazer, desaliena porque liberta da prisão do sensorial. O estádio estético é, afinal, um estádio de alienação. Sob esta perspetiva, a ironia é o reconhecimento da dimensão trágica da condição humana. É, ao mesmo tempo, a abertura para novas possibilidades que libertam o homem de possíveis imediatos. Kierkegaard pensava que a asfixia humana consistia na falta de possíveis, de perspetivas, na permanência num mundo em que as "portas da esperança" se fecham. A nova atitude, a atitude ética, é o abandono do hedonismo, do amoralismo, da irresponsabilidade, da máscara, da aparência e da dramatização simbólica. Significa, agora, a responsabilização, o comprometimento, a atenção aos valores.

O segundo estádio é o ético, o da exigência. Há um primado do dever: obediência ao dever que não é exterior, mas interior; dever de realizar o seu eu ideal. A moral surge como princípio regulador da conduta. O ético é o homem casado (herói da vida conjugal). O tempo está estabilizado. O tempo ético é o da continuidade, distinguindo-se, assim, da inconsistência e da descontinuidade do tempo estético, porque é o tempo do dever, da fidelidade a si mesmo e às normas morais. A honestidade, a justiça e a instalação, no geral, fazem o que toda a gente pode fazer. Neste estádio, formula-se sempre uma interdição (que surge como lei). $\mathrm{O}$ indivíduo não perde o seu caráter de ser único. Apaga-se no geral, mas não se apaga na massa populacional. $\mathrm{O}$ indivíduo combate contra a tendência para o prazer imediato, contra a exterioridade. A obediência generosa ao dever traz a felicidade. Mas há casos em que é impossível encontrar uma regra ética de conduta. 
O estádio ético é, apenas, passagem, na medida em que é contraditório. A sua mais elevada expressão é o arrependimento que acompanha a culpabilidade. A culpabilidade essencial não é imposta pela exterioridade, mas brota do próprio indivíduo a partir do momento em que ele se entregou à angústia e esta se apoderou dele.

O estádio ético é o da escolha assumida, o da decisão, o da aceitação das obrigações, das normas morais universais. A coerência, a hierarquização e diferenciação de valores, a dedicação às tarefas caraterizam o estádio ético, ideal do homem casado, do cidadão, do funcionário. Se o esteta encarna uma diversidade de figuras, o que faz a riqueza do homem ético é a escolha que faz de si próprio. Assim, ele está a caminho de ser o homem único procurando tomar-se naquilo que é. Trata-se de ser uma individualidade moral. O ético abdica da particularidade, porque a ação ética é a aspiração à universalidade, ao cumprimento do dever. Contudo, a realização do geral não significa, necessariamente, despersonalização (embora possa existir esse perigo). Trata-se, antes, de tomar concreto o abstrato, de individualizar o geral. O indivíduo é aquele que reconquista a sua interioridade. A atitude ética alimenta a convicção de que a obediência ao dever trará a felicidade. Esta atitude não pode subsistir quando não se experimenta a felicidade. $\mathrm{Na}$ infelicidade e no sofrimento, a atitude ética não pode desenvolver-se. O ético envolve o risco de o homem se esquecer de que é e deve ser um indivíduo, o risco de se perder na multidão, de se tomar um elemento passivo da massa populacional, na qual não há responsabilidade nem arrependimento. Na harmonia ética situa-se, igualmente, o desespero (Weston, 2003, p. 53). O paradoxo resulta da consciência de que o cumprimento do dever não toma o homem naquilo que quer e deve ser. Por isso se produz a necessidade de uma nova escolha, de um novo salto qualitativo. Este salto não é desprovido de angústia porque, por ela, se escolhe Deus, se abandona a ordem humana para optar pela ordem divina. Segundo Eduardo Lourenço:

[...] 'aos olhos de Deus temos sempre culpas', seja o que for que façamos. [...] Assim irrompe uma nova categoria, um novo horizonte humano, o religioso, cujo estatuto já não mura o homem na ordem do tempo, mas lhe assinala uma nova região cujas relações com o tempo são o seu repúdio: a eternidade. Mas como o homem está no tempo, o encontro com esse novo horizonte assinala o fim, o limite da situação humana. Esse encontro não poderá gerar senão a angústia e o escândalo. Num e noutro caso, o paradoxo. (Lourenço, 1987, p. 165).

A consciência da finitude, da limitação, da imperfeição e da impotência fazem da condição humana uma condição trágica. Nesta consciência sobre a existência, a consciência surge como uma doença, porque ser demasiado consciente acerca da sua existência constitui uma suprema desgraça do homem, uma consciência infeliz, que desencadeia a dinâmica da aproximação a Deus, a aspiração ao infinito, da qual o homem se sente separado. O finito é pensável em função do infinito; a busca progressiva do infinito conduz o homem à adesão aos valores estéticos e éticos: a beleza, o prazer, o dever. Contudo, a ironia e o humor, respetivamente as duas fronteiras entre o estético e o ético e entre o ético e o religioso, revelam a insuficiência desses estádios, a alienação que eles representam: alienado o homem estético, porque vive no instante prisioneiro dos valores estéticos; alienado o ético, porque prisioneiro do dever, dos valores morais. É impossível permanecer no estádio ético, pois, este não dá lugar à exceção religiosa e obriga o herói religioso a considerarse anormal. Esta revelação exige o salto para o estádio religioso como essência do ser humano. Apesar de superior ao estético, o estádio ético é inferior ao religioso. A crítica ao ético põe o homem em condições de dar o salto para o religioso.

O terceiro estádio é, precisamente, o religioso e carateriza-se pelo apelo à subjetividade profunda, à devoção, ao "Deus escondido". Este estádio comanda toda a dialética da existência conferindo-lhe o sentido 
da sua finalidade. Trata-se do domínio do infinito. Está para além do racional. Situa-se na esfera da fé que ultrapassa a razão e vai mesmo contra ela. A categoria fundamental do estádio religioso baseia-se no pressuposto de que não há instância superior à fé para julgar a fé. Neste estádio há uma relação pessoal com Deus. Ao mesmo tempo que se coloca o homem diante de Deus, revela-se o abismo que os separa, porque o homem é afetado pela doença mortal do pecado. O homem sabe que, perante Deus, é sempre culpado. O pecado é o melhor critério distintivo entre Deus e o homem. O religioso considera que Deus não está exterior ao homem, mas está no seu interior. A fé salva dos pecados. Para Kierkegaard, o religioso é o estádio em que o indivíduo se toma livre e é, ao mesmo tempo, a revelação da verdade como ato de liberdade, que não é escolha racional, mas um salto no desconhecido, motivado pela paixão, pela fé.

\section{Conclusões}

Qual é a pertinência dos três estádios da existência para a condição do indivíduo enquanto simples existente pessoal? A resposta a esta pergunta é o objetivo deste artigo: em primeiro lugar, compreender a posição de Kierkegaard sobre a importância da assunção de uma existência pessoal, numa perspetiva atemporal; em segundo lugar, refletir sobre a condição moderna do indivíduo à luz da posição existencialista de Kierkegaard. Efetivamente, a teoria dos três estados de existência é central na obra de Kierkegaard. Também é importante e pertinente independentemente da época em que se encontra o indivíduo.

No estádio estético, o homem procura valores fora de si em vez de os procurar em si mesmo; foge de si, aliena-se, representando uma variedade de papéis. O desespero pode ser a busca destes valores na exterioridade do indivíduo. Voltando-se para si e fechando-se em si, o indivíduo procura fazer de si um deus e coloca-se como protesto contra o divino. O desespero assume, nesta dimensão, a forma de desafio, recusa de Deus. Quer na fuga de si quer no desafio a Deus, o homem não consegue ser dono de si mesmo, ser ele próprio. Por isso, desespera. Não sentir nenhum desespero torna o homem mais desesperado, porque o indivíduo numa suposta ausência de desespero não estaria a existir humanamente, a viver, a ser ele próprio (Evans, 2006, p. 291). Estaria alienado. O desespero consiste em qualquer tentativa de escapar ao seu destino.

Também o estádio ético surge como percurso do desespero. A máxima "Escolhe-te a ti mesmo" é a que Kierkegaard coloca como fórmula de fidelidade a si mesmo e às normas do dever. A impossibilidade de realização do ético resulta em não se compadecer com o pecado, apesar de se exigir a conformidade com as normas morais comuns. Conformidade que aprisiona o indivíduo. Por isso, o ético é alienante. O regresso a si mesmo conduz à incomunicabilidade com os outros, à solidão. O desespero ético resulta da incapacidade de realização do geral e representa o fracasso do ético. Deste modo, o desespero prossegue no estádio seguinte, o religioso, porque a conceção de indivíduo para Kierkegaard é a de possibilidade existencial que se concretiza progressivamente. Segundo Nicola Abbagnano (1991, p. 10) aquilo que constitui sinal caraterístico da obra e da personalidade de Kierkegaard é o fato de ele ter procurado reconduzir a compreensão de toda a existência humana à categoria de possibilidade.

No estádio religioso, a imitação do Cristo sofredor na cruz garante a salvação (Evans, 2006, p. 249). Segundo a Bíblia, são bem-aventurados os que creem e sofrem, porque deles será o "Reino dos céus". Esta mensagem instaura uma espécie de otimismo sobre o sofrimento que salva. A esperança da salvação exige fé, obediência incondicional a Deus (Weston, 2003, p. 49; Moore, 2002, p. 98). O pecado resulta da desobediência. Obedecer é unir-se à vontade de Deus. O existente pessoal na sua interioridade é a categoria decisiva da religião cristã. A angústia, dimensão essencial da existência, compatibiliza-se com o desespero. $\mathrm{Na}$ 
perspetiva do existente pessoal de Kierkegaard, o desespero assume, portanto, várias formas.

Os obstáculos à diferença e singularidade do indivíduo e à verdadeira unidade interna conduzem ao desespero no estádio religioso. Neste estádio se toma consciência do pecado, da diferença radical de natureza entre o homem e Deus, da distância que os separa, da finitude do homem. A proposta de Kierkegaard, a dos estádios da existência que culminam na imitação de Cristo como forma de reencontrar a unidade e a esperança de salvação, conduz à unidade interior do homem e à verdadeira unidade antropológica que apenas com a fé se tomam possíveis (Evans, 2006, p. 80).

Por um lado, Kierkegaard reconhece a perfeição do indivíduo em ser ele próprio, mas, por outro lado, considera essa vontade como uma pretensão ilusória. De qualquer modo, o indivíduo nunca será ele próprio enquanto quiser apenas ser ele próprio, porque Kierkegaard considera que o indivíduo é algo mais do que ele próprio: é relação com Deus (Kierkegaard, 1947, p. 134).

A perfeição e a felicidade do indivíduo consistem em este ser ele próprio, mas em sê-lo totalmente. O indivíduo total é algo mais do que a sua própria natureza, na medida em que se depara com a divindade que o criou e com a qual é mais íntimo do que com a sua própria personalidade. Para Kierkegaard, o indivíduo apenas é autêntico perante Deus (Moore, 2002, p. xxvi).

É neste sentido que surge o conceito de "pecado", ou seja, quando o indivíduo se encontra desesperado e perante Deus (Kierkegaard, 1947, p. 131). O pecado é o indivíduo não querer ser ele próprio. Não existe pecado sem referência a Deus. A fé, sendo também uma condição para se considerar Deus, é o oposto do pecado, na medida em que consiste em aceitar e querer o poder criador (Kierkegaard, 1947: 134). O que é tido como "o mal” funciona também como garantia do cumprimento do que é estipulado e conveniente. O pecado é normalizador da conduta social ou, segundo Raul Iturra (1991, p. 23), representa uma capacidade mobilizadora.

A singularidade é uma conquista difícil, só alcançada através da coragem de ousarmos ser nós próprios, de ousarmos ser um indivíduo isolado, mas perante Deus (Kierkegaard, 1947, pp. 129-134). À coragem junta-se a luta e o sofrimento como requisitos fundamentais para a conquista do singular. Um singular que, para ser ele mesmo, exige um quadro de liberdade. Estas conquistas da singularidade e da liberdade estão inerentes e ambas pressupõem inevitavelmente a angústia. A existência autêntica é a existência do singular perante Deus. É, por conseguinte, a existência no estádio religioso da completude. Conforme reconhece Kierkegaard: "O Eu aumenta com a ideia de Deus e reciprocamente a ideia de Deus aumenta com o Eu. Só a consciência de estar perante Deus faz do nosso Eu concreto, individual, um Eu infinito" (Kierkegaard, 1947, p. 131).

Esta ideia kierkegaardiana de existência autêntica só tem cabimento no estádio religioso. Isso implica que se reconheça uma hierarquia dos estádios (estético, ético e religioso, no sentido do maior grau de exterioridade para o maior grau de interioridade) que, inclusivamente, mantêm relações entre si (Weston, 2003, p. 91). Isto significa que não se trata apenas de se situar num dos estádios e se excluir os outros, mas de se ser capaz e de se poder passar, de forma decidida e arriscada, de um para o outro (do estético ao ético e do ético ao religioso) em momentos de crise existencial. Por exemplo, a passagem do estético para o ético não significa a aniquilação do estético, mas a sua transfiguração através da arte de dominar o prazer. Assim, até se pode dizer que o estádio ético é que salva o que existe de positivo no estético. Também o religioso, considerado irredutível face à moral, coloca o ético à sua disposição, de modo a permitir as realizações e as experiências anteriormente impossíveis. Assim, não existem estádios puros.

Esta posição de Kierkegaard opõe-se à de Kant. Este defende que, em nome da moral, Abraão não deveria dispor-se a imolar o seu filho Isaac, porque o que lhe foi proposto contraria a lei moral (Kant, 1973, 
p. 73). Enquanto Kant dá prioridade à lei moral sobre a ordem de Deus, Kierkegaard considera a superioridade do religioso sobre o ético. Ao propor uma hierarquia de estádios, coloca o religioso como o supremo, sendo Abraão o herói da fé, o paradigma do homem religioso (Evans, 2006, p. 215). Entre optar pelo ético ou pela fé incondicional em Deus, entre a razão e a crença, a opção de Abraão, livre e responsável, foi a fé em Deus. Por isso, é exaltado por Kierkegaard (1998, pp. 39-44).

A ação humana é limitada dentro de um quadro de possibilidades. Quando os seres humanos se tornam conscientes das suas limitações, têm a oportunidade de demonstrar dignidade. Esta não reside no que é adquirido pela sua natureza, mas no que pode alcançar pela sua liberdade e ação. As opções que se fazem, em função dos valores que se considera prioritários, moldam o modo de ser. A este propósito, Ricoeur (1988, p. 391) refere-se à "liberdade do ato de fé", ou seja, a liberdade de crença ou poder geral de escolher e produzir uma opinião, uma convicção subjetiva.

Esta liberdade tem limites numa outra liberdade religiosa, a de professar uma crença determinada ou expressar publicamente a fé na forma da opinião. Pressupõe-se a grandeza moral e cultural de reconhecer o outro como sujeito de vontade livre no seio de uma mesma comunidade organizada de direito público. Esta forma de liberdade confina-se no conteúdo da crença religiosa que a alimenta e que, paradoxalmente, assenta na esperança. A esperança aprisiona a fé de quem tem esperança, em vez de o libertar totalmente. A liberdade da esperança é o sentido de uma existência humana dependente da ressurreição ou de uma resposta do futuro. Para Kierkegaard, a liberdade segundo a esperança é a paixão pelo possível (Ricoeur, 1988, p. 427).

Em suma, Kierkegaard abre uma via para a crise da razão na História das Ideias, porque a aproximação a Deus não se pode fazer, segundo o autor, pela via racional, mas pela via da fé que aponta para aquilo que a razão não considera. Kierkegaard opõe-se, neste ponto, a uma teologia cristã que procura provar, racionalmente, a existência de Deus. Os visados são: São Tomás de Aquino, Santo Anselmo, Descartes ou Espinosa.

\section{Referências}

ABBAGNANO, N. (1946-50). História da Filosofia (vol. IX). Tradução: Conceição Jardim, Eduardo Lúcio Nogueira e Nuno Valadas. Lisboa: Editorial Presença, 1991.

BLACKBURN, S. (1994). Dicionário de Filosofia. Tradução: Desidério Murcho, Pedro Galvão, Ana Cristina Domingues, Pedro Santos, Clara Joana Martins e António Horta Branco. Lisboa: Gradiva, 1997.

BOBBIO, N. (1948). El Existencialismo: Ensayo de Interpretación. Tradução: Octavio G. Barreda. México: Fondo de Cultura Económica, 1951.

COPLESTON, F. (1978). Historia de la Filosofía - Vol. VII: De Fichte a Nietzsche. Tradução: Ana Doménech. Barcelona: Editoral Ariel, 1996.

ESPINOSA, B. (1677). Ética. Tradução: Joaquim de Carvalho, Joaquim Ferreira Gomes e António Simões. Lisboa: Relógio d’Água, 1992.

EVANS, C. S. (2006). Kierkegaard on Faith and the Self. Waco, Texas: Baylor University Press, 2006. HARTMANN, N. (1923-29). A Filosofia do Idealismo Alemão. Tradução: José Gonçalves Belo. Lisboa: Fundação Calouste Gulbenkian, 1983.

HEGEL, G. W. F. (1821). Philosophy of Right. Tradução: S. W. Dyde. Ontario: Batoche Books, 2001.

HEGEL, G. W. F. (1807). Fenomenología del Espíritu. Tradução: Wenceslao Roces. México: Fondo 
de Cultura Económica, 2004.

HEIDEGGER, M. (1962). The Question Concerning Technology and Other Essays. Tradução: William Lovitt. New York: Garland Publishing, 1977.

HOWLAND, J. (2006). Kierkegaard and Socrates: A Study in Philosophy and Faith. Cambridge: Cambridge University Press, 2006.

ITURRA, R. (1991). A Religião como Teoria da Reprodução Social. Lisboa: Escher.

JOLIVET, R. (1948). As Doutrinas Existencialistas: de Kierkegaard a Sartre. Tradução: António de Queirós Vasconcelos e Lencastre Porto: Livraria Tavares Martins, 1975.

KANT, I. (1798). Le Conflit des Facultés. Tradução: Jean Gibelin. Paris: Vrin, 1973.

KIERKEGAARD, S. (1849). O Desespero Humano - Doença Até à Morte. Tradução: Adolfo Casais Monteiro. Porto: Livraria Tavares Martins, 1947.

KIERKEGAARD, S. (1843). Temor e Tremor. Tradução: Maria José Marinho. Lisboa: Guimarães Editores, 1998.

KIERKEGAARD, S. (1859). Ponto de Vista Explicativo da Minha Obra como Escritor. Lisboa: Edições 70, 1986.

KIERKEGAARD, S. (1846). Concluding Unscientific Postscript. Tradução: Alastair Hannay. Cambridge: Cambridge University Press, 2009.

LEIBNIZ, G. W. (1714). A Monadologia. Tradução: António Novais Machado. Coimbra: Casa do Castelo - Editora, 1947.

LOURENÇO, E. (1987). “Sören Kierkegaard, Espião de Deus”, In: Heterodoxia. Lisboa: Assírio \& Alvim, 1987.

MARÍAS, J. (1941). História da Filosofia. Tradução: Cláudia Berliner. São Paulo: Martins Fontes, 2004.

MOORE, C. E. (2002). Provocations: Spiritual Writings of Kierkegaard. Robertsbridge, East Sussex: The Bruderhof Foundation, 2002.

MOREAU, J. (1971). Espinosa e o Espinosismo. Tradução: Lurdes Jacob e Jorge Ramalho. Lisboa: Edições 70, 1982.

NIETZSCHE, F. (1889). O Crepúsculo dos Ídolos. Tradução: Delfim Santos. Lisboa: Guimarães Editores, 2002.

PLATÃO (1949). República. Tradução: Maria Helena da Rochas Pereira. Lisboa: Fundação Calouste Gulbenkian, 2001.

PLATÃO (1995). Teeteto. Tradução: Adriana Manuela Nogueira e Marcelo Boeri. Lisboa: Fundação Calouste Gulbenkian, 2005.

PLATÃO (2009). Apologia de Sócrates. Tradução: Pinharanda Gomes. Lisboa: Guimarães Editores, 2009.

RICOEUR, P. (1969). O Conflito das Interpretações. Tradução: M. F. Sá Correia. Porto: Rés-Editora, 1988.

WAHL, J. (1959). As Filosofias da Existência. Tradução: A. Torres e I. Lobato. Lisboa: Publicações Europa-América, 1962. 
WATKIN, J. (2001). Historical Dictionary of Kierkegaard's Philosophy. Oxford: The Scarecrow Press. WESTON, M. (1994). Kierkegaard and Modern Continental Philosophy: An Introduction. London: Routledge, 2003.

Artigo recebido em: 01 de junho de 2020

Artigo aceito em: 10 de julho de 2020 